LINGUA, Vol. 16, No. 2, September 2019

p ISSN: 1979 9411; e ISSN: 2442 238X

Http://lingua.soloclcs.org; Email: presslingua@gmail.com

Center of Language and Cultural Studies, Surakarta, Indonesia

Wahyuni, Wika; Mahyuni \& Mahyudi, Johan. 2019. Ekspresi Tabu Bahasa Wanita pada Status dan Komentar di Jejaring Sosial Istragram.

Lingua (2019), 16(2): 285-296. Http://doi.org/10.30957/lingua.v16i2.270.

\title{
Ekspresi Tabu Bahasa Wanita pada Status dan Komentar di Jejaring Sosial Instagram
}

\author{
Wika Wahyuni, Mahyuni \& Johan Mahyudi \\ Magister Pendidikan Bahasa Indonesia Universitas Mataram \\ Jalan Majapahit No. 6 Mataram Nusa Tenggara Barat \\ Corresponding E-mail: wahyuniwika70@yahoo.com
}

\begin{abstract}
This research is based on differences in the variety of languages of women and men in society. The research is focused on the taboo language used by women in written form on the Instagram social network. The use of taboo language by men is more accepted in society. The formulation of the premise of this study is to determine the forms of female taboo expressions on Instagram. This research is a qualitative descriptive study that is based on the use of taboo language on Instagram. The purpose of this study is to describe the forms of taboo expressions written by women on Instagram. The process of data collection was done by referring to the record anddocumentation method. Data were analyzed using taboo theory according to Wijana (2006) and Timothy Jay (1996). The results of the analysis showed that women use taboo language expressions which are vulgar, sexually harassing, name-calling and insulting.
\end{abstract}

Keywords: taboo language, women, Instagram

\section{PENDAHULUAN}

Dalam kajian sosiolinguistik, ada beberapa faktor yang mempengaruhi munculnya ragam bahasa. Faktor tersebut antara lain adalah faktor geografis dan faktor sosial. Jika faktor geografis disebabkan oleh adanya jarak atau perbedaan tempat, maka faktor sosial disebabkan oleh adanya perbedaan tingkatan sosial di masyarakat.

Selain kedua faktor tersebut, ragam bahasa juga bisa muncul disebabkan oleh perbedaan gender. Walaupun hal ini tidak selalu berlaku dalam masyarakat, namun pada beberapa wilayah ternyata menunjukkan adanya perbedaan yang cukup signifikan antara bahasa wanita dan pria. Perbedaan gender ini memunculkan penggunaan kosa kata berlainan antara wanita dan pria yang didasari tujuan tertentu.

Sebagai bentuk dari adanya perbedaan gender, maka muncul pengelompokan karakteristik atau sifat-sifat yang menjadi ciri khas bahasa wanita dan pria. Bahasa pria dinilai lebih tegas, matang, suka berbicara terang-terangan, pengunaan kata makian dan kata-kata tabu diterima. Sebaliknya, bahasa wanita dianggap tidak tegas, tidak secara terang-terangan (menggunakan kata-kata kiasan), dan berhati-hati ketika mengemukakan sesuatu, serta kerap menggunakan kata yang lebih halus dan sopan atau melalui isyarat.

Klasifikasi karakteristik bahasa wanita dan pria tersebut menggiring pemikiran publik untuk mengakui/mematenkan dan menciptakan aturan dalam kehidupan sosial 
LINGUA, Vol. 16, No. 2, September 2019

p ISSN: 1979 9411; e ISSN: 2442 238X

Http://lingua.soloclcs.org; Email: presslingua@gmail.com

Center of Language and Cultural Studies, Surakarta, Indonesia

Wahyuni, Wika; Mahyuni \& Mahyudi, Johan. 2019. Ekspresi Tabu Bahasa Wanita pada Status dan Komentar di Jejaring Sosial Istragram.

Lingua (2019), 16(2): 285-296. Http://doi.org/10.30957/lingua.v16i2.270.

bermasyarakat. Jika laki-laki berbicara/berbahasa menggunakan kata-kata tabu dan kasar, maka hal tersebut dapat diterima dan dianggap wajar. Sementara, wanita akan dinilai negatif jika menggunakan kata-kata tabu atau kata-kata yang dianggap kotor (kasar).

Pada beberapa rentang waktu, khususnya di Indonesia, bahasa tabu sebagai bahasa yang hanya boleh diucapkan pria diakui dan dipandang lumrah oleh masyarakat. Namun, seiring perkembangan zaman dan teknologi yang sangat pesat memunculkan tuntutan kesetaraan wanita dan pria dalam seluruh aspek kehidupan, termasuk penggunaan bahasa. Walaupun, tidak dapat diabaikan pula fakta bahwa pada beberapa wilayah masih berpegang teguh pada konstruksi sosial yang telah disepakati sebelumnya.

Salah satu bentuk dari perkembangan teknologi, terutama komunikasi, adalah jejaring sosial. Jejaring sosial menjadi salah satu kebutuhan yang tidak terlepas dari kehidupan manusia. Sebagian besar masyarakat tanpa memandang latar belakang usia, ekonomi, dan sosial memiliki akun pada jejaring sosial tersebut. Jenis jejaring sosial pun kini semakin beragam dan terus berkembang dari waktu ke waktu. Beberapa jenis jejaring sosial yang tengah populer di dunia, termasuk di Indonesia antara lain adalah Facebook, Instagram, Path, Tumblr, Social Chat Apps seperti BBM, Line, dan Whatsapp.

Keberadaan jejaring sosial (dalam penelitian ini berfokus pada instagram) memudahkan terjalinnya komunikasi yang terpisah jarak. Bentuk komunikasi yang digunakan pada instagram adalah ragam tulis. Masyarakat dapat berkomentar dengan menuliskan pandangan mereka secara bebas dan ekspresif, bahkan tanpa batas. Situasi ini secara perlahan namun pasti menjadi wadah bagi masyarakat, khususnya wanita untuk bisa berkomentar apa pun. Hal ini akhirnya berimbas juga pada terkikisnya aturan-aturan tentang karakteristik atau sifat-sifat bahasa yang seharusnya dan tidak seharusnya digunakan oleh wanita.

Bahasa wanita di jejaring sosial instagram tidak lagi halus dan sopan. Bahasa tabu seperti kata-kata kotor, kasar, sumpah serapah, dan umpatan bukan lagi hanya milik pria, namun digunakan pula oleh wanita dalam mengekspresikan gagasan dan opininya terhadap sesuatu yang tengah menjadi perbincangan hangat di instagram. Fenomena ini dapat kita temui pada akun-akun gosip di instagram yang sebagian besar anggotanya (Follower: istilah Instagram) adalah wanita dari berbagai latar belakang sosial, budaya, dan usia.

Dengan demikian, penelitian ini akan mencoba menyajikan bentuk-bentuk ketabuan bahasa tulis wanita yang terdapat pada status maupun komentar-komentar di jejaring sosial instagram. Tujuannya adalah menunjukkan bahwa ternyata perkembangan zaman dan teknologi, terutama teknologi komunikasi juga berpengaruh pada kebebasan berbahasa wanita dan mengubah karakteristik ragam bahasa gender yang telah dikelompokkan oleh para ahli sebelumnya. 
LINGUA, Vol. 16, No. 2, September 2019

p ISSN: 1979 9411; e ISSN: 2442 238X

Http://lingua.soloclcs.org; Email: presslingua@gmail.com

Center of Language and Cultural Studies, Surakarta, Indonesia

Wahyuni, Wika; Mahyuni \& Mahyudi, Johan. 2019. Ekspresi Tabu Bahasa Wanita pada Status dan Komentar di Jejaring Sosial Istragram.

Lingua (2019), 16(2): 285-296. Http://doi.org/10.30957/lingua.v16i2.270.

\section{LANDASAN TEORI}

Secara teoritis penelitian ini didasari teori gender dan teori tabu.Gender dalam studi tentang bahasa dan gender, istilah "gender" bukanlah sinonim dari "jenis kelamin (sex)". Seks mengacu pada perbedaan biologis yang merupakan pemberian dari Tuhan, sedangkan gender merupakan istilah yang digunakan untuk menggambarkan kategorikategori dan konstruksi yang terbentuk secara sosial budaya berdasarkan jenis kelamin.Istilah gender pertama kali diperkenalkan oleh Stoller (1968) memisahkan pencirian manusia yang didasarkan pada pendefinisian yang bersifat sosial budaya dengan pendefinisian yang berasal dari ciri-ciri fisik biologis.

Nugroho (2008) mengemukakan bahwa gender adalah pembedaan peran perempuan dan laki-laki yang dibentuk oleh konstruksi sosial dan kebudayaan, sedangkan jenis kelamin adalah sesuatu yang dibawa sejak lahir. Berdasarkan hal tersebut, maka gender adalah sesuatu yang dibentuk karena pemahaman yang tumbuh dan berkembang dalam masyarakat.

Menurut Oakley (1972), gender merupakan sebuah bentuk diferensiasi antara pria dan wanita (behavioral differences) yang dikonstruksi secara sosial atau berlangsung dalam sebuah proses sosial dan kultural. Gender lebih menitikberatkan pada peran sosial dalam lingkungan masyarakat yang terbentuk melalui proses sosial dan budaya. Berikut tabel asosiasi sifat dan karakteristik perempuan dan laki-laki berbahasa menurut Lips (1988:4).

Robin Tolmach Lakoff adalah seorang profesor linguistik di Universitas California, Berkeley. Dia menjadi linguis pertama yang memulai penelitian mengenai fitur-fitur tuturan perempuan. Menurutnya, bahasa yang digunakan oleh perempuan tidak tegas, tidak secara terang-terangan (menggunakan kata-kata kiasan), dan berhatihati ketika mengemukakan sesuatu, serta kerap menggunakan kata yang lebih halus dan sopan atau melalui isyarat. Beberapa ahli juga menyatakan bahwa wanita bersifat hiperkorek dan androgini. Kedua sifat ini menyebabkan wanita dianggap kurang layak untuk dijadikan informan dalam penelitian.

Selanjutnya, Lakoff (1975) menyebutkan bahwa terdapat banyak hal yang menjadi dasar munculnya perbedaan antara perempuan dan laki-laki dalam berbahasa. Digambarkan bahwa bahasa laki-laki lebih tegas, matang, dan laki-laki suka berbicara terang-terangan dengan kosakata yang tepat. Karakteristik bahasa laki - laki menurut Holmes (1992) adalah seperti ungrammatical form, multiple negations, pronounced -in form, delete -ed at the end of form in pronunciation, dan impolite forms.

Teori tentang perbedaan bahasa perempuan dan bahasa laki-laki secara linguistik menggunakan teori yang ditulis oleh Coates (1986). Kemudian Coates (1986) menyatakan bahwa bahasa pada laki-laki lebih banyak menggunakan kata kerja (verbosity), pertanyaan (question), perintah (command), kata-kata kasar (swearing) and bahasa pantangan (taboo language), tidak gramatikal (ungrammatical), dan jelas (to the point).

Oleh karena itu, bahasa laki-laki dianggap sebagai bahasa normatif. Tuturan laki-laki bersifat referensial dan kompetitif. Pengunaan kata makian dan kata-kata tabu diterima, laki-laki sering menggunakan kata makian yang kasar dan terlarang. 
LINGUA, Vol. 16, No. 2, September 2019

p ISSN: 1979 9411; e ISSN: 2442 238X

Http://lingua.soloclcs.org; Email: presslingua@gmail.com

Center of Language and Cultural Studies, Surakarta, Indonesia

Wahyuni, Wika; Mahyuni \& Mahyudi, Johan. 2019. Ekspresi Tabu Bahasa Wanita pada Status dan Komentar di Jejaring Sosial Istragram.

Lingua (2019), 16(2): 285-296. Http://doi.org/10.30957/lingua.v16i2.270.

Penggunaan imperatif yang murni tanpa menambahkan kata-kata apapun seperti "tolonge adalah hal yang biasa dan lumrah. Memotong pembicaraan orang lain dianggap hal yang biasa. Lebih sering mengajukan pertanyaan. Pujian dan permintaan maaf diminimalkan karena itu dianggap merendahkan posisinya. Bahasa digunakan sebagai alat kekuasaan. Kemudian, laki-laki cenderung memilih bentuk tidak baku lebih disukai dari bentuk yang baku.

Selanjutnya, teori lain yang digunakan adalah teori tabu. Pengertian tabu di sini tidak hanya menyangkut ketakutan terhadap roh gaib, melainkan juga berkaitan dengan sopan santun dan tata krama pergaulan sosial, orang yang tidak ingin dianggap tidak sopan akan menghindarkan penggunaan kata-kata tertentu, contohnya adalah dalam masyarakat Indonesia, terutama dalam bahasa daerah, sering dikatakan wanita lebih banyak menghindari penggunaan kata-kata yang berhubungan dengan alat kelamin atau kata-kata kotor yang lain (Sumarsono, 2012).

Hubungan teori tabu dengan variasi penggunaan bahasa pria dan wanita yaitu wanita lebih jarang menggunakan kata-kata yang tabu dibandingkan pria. Tabu memegang peranan penting dalam bahasa. Hal ini karena tabu tabu sebagai akibat berubahnya makna kata. Sebuah kata yang ditabukan tidak dipakai, kemudian digunakan kata lain yang sudah mempunyai makna tersendiri. Akibatnya kata yang tidak ditabukan itu memperoleh beban makna tambahan. Selain menyangkut ketakutan terhadap roh gaib, tabu juga berkaitan dengan nilai kesopanan dan tata krama pergaulan sosial, orang yang tidak ingin dianggap tidak sopan akan menghindarkan penggunaan kata-kata tertentu.

Dalam masyarakat Indonesia terutama dalam bahasa daerah, sering dikatakan wanita lebih banyak menghindarkan penggunaan kata-kata yang berhubungan dengan alat kelamin atau kata-kata kotor yang lain. Kata-kata ini ditabukan wanita, atau menjadi monopoli pria. Contoh di Zulu, Afrika, dalam bahasa Zulu ada kata-kata tertentu yang ditabukan oleh wanita. Apabila kata-kata itu mengandung bunyi /z/. Wanita tersebut tidak akan mengucapkannya, karena itu harus mengubahnya ke dalam menjadi kata-kata lain.

Bentuk tabu sendiri berdasarkan teori terbagi menjadi 3 jenis, yaitu tabu yang menakutkan (taboo of fear), tabu yang menyebabkan perasaan tidak nyaman (taboo of delicacy), dan tabu yang berkaitan dengan hal-hal tidak santun dan tidak pantas (taboo of propriety) (Wijana, 2006:11). Sementara itu, menurut Timothy Jay, seorang professor psikologi di Massachusetts College of Liberal Arts, mengkategorikan kata tabu (taboo words) menjadi 7, yaitu:

1. Mengutuk (Cursing)

Menurut Timothy Jay salah satu kategori tabu atau "kata kotor" yang paling umum adalah mengutuk. Dia menentukan "kutukan" berdasarkan pada satu usaha untuk "menyakiti perasaaan orang lain dengan menggunakan kata atau frasa tertentu(Jay, 1996:8).

2. Kata Tidak Senonoh (Profanity)

Jaymenulis "Senonoh berarti bersifat duniawai atau tidak tahu atau tidak toleranterhadap petunjuk aturan agama tertentu., tapi ketidak senonohan 
bukanlah seranganlangsung terhadap agama atau gereja (1996:10). Contoh penggunaan kata yang tidaksenonoh misalnya "For the love of Christ, get off the phone!" (Jay, 1996:10). Jaymenyebutkan bahwa bahasa seperti itu telah menjadi hal yang biasa dan lunak. "Kitabegitu sering mendengarkan kata tidak senonoh sehingga kita tidak lagimemperhatikannya dan tidak mengenali seberapa sering ia diucapkan (1996:10). Diajuga menyebutkan bahwa ketidaksenonohan itu terdiri atas "setengah dari semuabahasa yang ada dan dipertanyakan dalam televise dan film yang mungkin akandidengar oleh anak-anak. (1996:10).

3. Penghujatan (Blashphemy)

Penghujatan juga memiliki tempat dalam leksikon agama seperti yangdisebutkan oleh Jay dan Montagu. Namun perbedaannya ada pada cara bahasanyamemperlakukan agama. Profanity tidak secara langsung mengkritik gereja atau agama,sedangkan penghujatan secara langsung mengarah pada gereja dan figur agama (Jay,1996:2).

4. Kecabulan (Obscenety)

Jay memasukkan istilah ini ke ranah hukum "kecabulan"yang disebut sebagai "pembicaraan yang tidak dilindungi" (1996:14). Dengan istilahini, tabu telah kalah. Jay menulis "Jika pemikiran tentang tabuu membatasi ataumencegah apa yang akan dikatakan penutur, kecabulan berfungsi untukmelingdungipendengar dari bahasa yang berbahaya (1996:14). Jay mencatat bahwa tabu memilikikekuatan lebih dalam "isi pembicara" untuk melindungi penutur (1996:14). Di Amerika, sama seperti di banyak budaya lain, kecabulan biasanya berkaitan denganseks. Tabu atau kata yang paling cabul adalah kata 'fuck' (1996:15).

5. Pelecehan Seksual (Sexual Harassment)

Pemisahan untuk definisi yang sudah diterimasekarang ini digambarkan sebagai "komentar seksual yang tidak diinginkan, gurauanjorok, penunjukkan pada penampilan atau perilaku seksual seseorang." (Jay 1996:17).

6. Bahasa Vulgar (Vulgar Language)

Vulgar berarti "bahasa dariorang biasa"(jay, 1996:19). Definisi ini menujukkan pada apa yang disebut Jaysebagai "linguistic snobbery" dimana dulu pada masa Raja William, yang menerbitkanbahasa perancis sebagai bahasa kekuasaan. Mereka terus menerus merubah istilahnyasehingga orang dari kalangan bawah tidak akan dapat memahami maksudnya. Padaakhir abad 19, bahasa vulgar dikaitkan dengan seks. Istilah vulgar yang saat ini seringdipakai meliputi "snot, bloody, up yours, boobs, slut (Jay, 1996:20). Vulgaritas adalahfenomena yang terstruktur secara sosial dan dianggap sebagai penanda status sosial(1996:20). Kata vulgar tergantung pada konteksnya "beberapa masyarakat mungkin akanmenghasikan lebih banyak kevulgaran dibanding masyarakat lain, tergantung pada masyarakat yang berlaku, kecerdasan, kondisi ekonomi dan nilai yang berlakudimasyarakat (Jay, 1996:20).

7. Penyebutan-Nama dan Hinaan (Name-Calling and Insult) 
LINGUA, Vol. 16, No. 2, September 2019

p ISSN: 1979 9411; e ISSN: 2442 238X

Http://lingua.soloclcs.org; Email: presslingua@gmail.com

Center of Language and Cultural Studies, Surakarta, Indonesia

Wahyuni, Wika; Mahyuni \& Mahyudi, Johan. 2019. Ekspresi Tabu Bahasa Wanita pada Status dan Komentar di Jejaring Sosial Istragram.

Lingua (2019), 16(2): 285-296. Http://doi.org/10.30957/lingua.v16i2.270.

Jay mendefinisikan satu kategori tabu bahasa yang terakhir, yang kita pikirmemiliki hubungan denganmengutuk. Kategori ini adalah "hinaan, penyebutan namadan penghinaan etnis. Seperti mengutuk, kata seperti itu diucapkan dengan tujuanuntuk menyakiti, merendahkan, dan memburukkan pendengar (Jay, 1996:22).

\section{METODE}

Penelitian ini merupakan penelitian deskriptif kualitatif yang bertujuanmendeskripsikan bagaimana bentuk ekspresi bahasa tabu yang digunakan wanita dalam tulisan di jejaring sosial instagram. Data dikumpulkanmenggunakan teknik simak dan dokumentasi. Metode simak adalah teknik memperolehdata dengan cara menyimak penggunaan bahasa (Mahsun, 2007:92). Penelitian inimenggunakan metode simak dengan teknik lanjutan simak bebas libat cakap,maksudnya peneliti melakukan pengamatan dengan cara menyimak teks-teks status dan komentaryang diunggah oleh para pengguna wanita di jejaring sosial instagram. Dalam penelitian ini, ada beberapa tahapan dalam mengumpulkan data. Pada tahap awal, peneliti membaca status dan komentar para pengguna wanitadi jejaring sosial instagram secara berulangulang untuk menemukan ekspresi bahasa tabu. Metode simak memiliki teknik dasar yang berwujud teknik sadap. Teknik sadap disebut teknik dasar karena pada hakikatnya penyimakan diwujudkan dengan penyadapan. Dalam arti, penelitian dalam upaya mendapatkan data dilakukan dengan menyadap penggunaan bahasa seseorang atau beberapa orang yang menjadi informan (Mahsun, 2013:92-93).

Jadi langkah selanjutnya setelah menyimak adalah menerapkan teknik sadap. Data-data berupa teks yang mencerminkan fokus permasalahan akan disadap secara keseluruhan.Dalam penelitian ini, peneliti hanya mengamati peristiwa tuturan dalam jejaring sosial tanpa terlibat komunikasi dengan penulis status di instagram. Berdasarkan hal tersebut, teknik lanjutan yang digunakan adalah teknik simak bebas cakap. Artinya, peneliti tidak terlibat langsung dalam aktivitas komunikasi yang akan diteliti (Mahsun, 2013:93).

Setelah itu, peneliti lanjutkan dengan teknik catat. Teknik catat merupakan gandengan dari teknik simak bebas cakap, yakni berfokus pada objek kajian yang berupa wacana tulis atau teks. Teknik catat digunakan untuk mencatat beberapa bentuk yang relevan untuk diseleksi dalam penelitian. Peneliti mengidentifikasi data-data yang memuat ekspresi bahasa tabu kemudian memberi kode/tanda. Hal ini dimaksudkan untuk mempermudah peneliti untuk mencari dan mengelompokkan data. Pengelompokkan data ditentukan berdasarkan bentuk tabu menurut teori Timothy Jay.

Selain menggunakan metode simak, peneliti juga menggunakan metode dokumentasi. Data yang digunakan dalam penelitian kualitatif sebagian besar diperoleh dari sumber manusia atau human resources, sedangkan sumber lain yang bukan dari manusia (non-human resources) di antaranya berupa dokumen, foto, dan bahan statistik. Dokumen juga bisa berupa surat-surat resmi, buku harian, peraturan pemerintah, anggaran dasar, rapor siswa dan lain sebagainya. 
Dalam penelitian ini, peneliti menggunakan foto sebagai data. Dengan menggunakan foto dapat menunjukkan bentuk asli yang terdapat dalam jejaring sosial. Metode dokumentasi ini peneliti anggap sangat tepat digunakan dalam penelitian yang akan dikaji. Teknik yang digunakan adalah dengan cara mengunduh atau mengcapturestatus dan komentar yang memuat ekspresi bahasa tabu wanita.

Dalam penelitian ini, metode padan intralingual dan metode padan ekstralingual menggunakan teknik lanjutan. Teknik-teknik lanjutan tersebut yaitu teknik hubung banding menyamakan (HBS), hubung banding membedakan (HBB), dan hubung banding menyamakan hal pokok (HBSP) (Mahsun, 2013:121). Adapun langkahlangkah yang akan dilakukan dalam proses analisis data sebagai berikut.

1) Identifikasi. Peneliti menelaah seluruh data yang diperoleh melalui hasil simak dengan tujuan mengetahui data tersebut berupa ekspresi bahasa tabu wanita pada status dan komentar di jejaring sosial instagram.

2) Data yang sudah diidentifikasi akan dianalisis menggunakan metode dan teknik yang sesuai dengan data. Jika data tersebut dapat dianalisis berdasarkan struktur bahasanya, maka dapat menggunakan metode padan intralingual dan teknik lanjutannya yang sesuai. Namun, jika data berkaitan dengan konteks di luar bahasa, maka analisis dilakukan dengan menggunakan metode padan ekstralingual dan teknik lanjutannya.

3) Tahapan selanjutnya adalah mengklasifikasi data sesuai kategori. Pada tahap ini, data dikelompokkan sesuai kategori bahasa tabu Timothy Jay.

Tahapan terakhir adalah menarik kesimpulan berdasarkan hasil analisis data.

Hasil analisis data dalam penelitian ini disajikan dengan menggunakan metodepenyajian informal. Penyajian hasil analisis data secara informal adalah penyajian hasilanalisis data dengan menggunakan kata-kata yang biasa (Sudaryanto, 1993:145).Dalam penyajian ini, kaidah-kaidah disampaikan dengan kata-kata biasa, kata-kata yangapabila dibaca dengan serta merta dapat langsung dipahami. Kaidah itu berupa ekpresibahasa tabu wanita yang terdapat dalam status dan komentar di instagram.

\section{HASIL DAN PEMBAHASAN}

Berdasarkan data yang diperoleh melalui metode simak dan dokumentasi (screenshoot) di instagram, telah ditemukan beberapa bentuk bahasa tabu yang ditulis oleh pengguna wanita. Bentuk tabu sendiri berdasarkan teori terbagi menjadi 3 jenis, yaitu tabu yang menakutkan (taboo of fear), tabu yang menyebabkan perasaan tidak nyaman (taboo of delicacy), dan tabu yang berkaitan dengan hal-hal tidak santun dan tidak pantas (taboo of propriety).

Pada penelitian ini, bentuk tabu yang ditemukan adalah jenis ketiga yaitu tabu yang berkaitan dengan hal-hal yang dianggap tidak santun dan tidak pantas (taboo of propriety). Hal-hal yang dianggap tidak pantas dan santun tersebut seperti penyebutan alat kelamin atau istilah yang tidak senonoh (vulgar), makian yang merendahkan dengan 
kata-kata kasar, dan hinaan dengan mengumpamakan/menyamakan orang dengan hewan atau sesuatu yang dianggap buruk. Berikut disajikan data beserta analisisnya.

(1) Hahaha emang dia berang2 bukan barbie, lagian lu sih@barbiekumalasari Alias berang2 kali ngapain sih keliaran udh ngeram aja di kali sih biar bersih tu otak lu jg

\section{Kategori: Insult}

Data (1) memuat bentuk tabu yang berisi hinaan dengan menyamakan manusia dengan hewan, yaitu berang-berang. Tujuan penulisan komentar tersebut adalah menghina dan merendahkan. Selain kata berang-berang, penanda verbal lain yang menunjukkan hinaan adalah /... ngapain sih keliaran udh ngeram aja di kali sih biar bersih tu otak lu jg/

(2) Ya ampun ini org niat hati pasti pengen glowing tu muka laa malah jatuhnya kayak oli kececer di aspal, astagfirullah

\section{Kategori: Insult}

Data (2) memuat bentuk hinaan dengan menyamakan manusia dengan oli yang berceceran di aspal (/...oli kececer di aspal/). Penulis komentar bermaksud mengatakan bahwa wajah yang dimaksud buruk/jelek.

(3) Minta di aspal itu muka lawyer gembel. Ga belajar bahasa kayanya... mampus loe masuk kandang macan. Pengen bgt terkenal

\section{Kategori: Insult}

Data (3) memuat bentuk hinaan dengan mengatakan orang lain (yang berprofesi sebagai pengacara (lawyer)) gembel. Gembel sendiri menurut KBBI berarti melarat atau miskin sekali.

(4) Saat menjadi pelacur tidak lg merasa malu

\section{Kategori: Vulgar language}

Data (4) memuat bentuk hinaan dengan mengatakan orang lain (yang juga wanita) sebagai pelacur. Pemilihan kata pelacur merupakan bentuk tindakan merendahkan wanita, apalagi penutur juga adalah seorang wanita.

(5) Bangke tuh sih babu. Bikin2 heboh aja di TV. Dia ga tau 1 Indonesia pengen muntah kalo liat muka tuh boneka Chucky sama sih mokontol yg isi perutnya itu uler dr titisan sih suing

Kategori: Vulgar language, Name-calling and Insult 
Data (5) memuat bentuk hinaan merendahkan seseorang dengan penyebutan babu. Kata babu sendiri merupakan bentuk paling kasar dari pembantu. Selain merendahkan, data (5) juga memuat kata vulgar yaitu mokontol. Mokontol merupakan akronim dari modal kontol. Kata tersebut dianggap masyarakat sebagai bahasa tabu untuk diucapkan, apalagi jika diucapkan oleh wanita.

(6) Oh jadi pas tadi gw liat meldi di tempat sampah itu ini alasannya.. ternyata dia cari koran bekas buat dijadiin celana. Sungguh miris org misquueen

\section{Kategori: Insult}

Data (6) memuat bentuk hinaan dengan penyebutan tempat sampah dan orang miskin (yang juga wanita). Penulis status bertujuan merendahkan orang lain dengan menyebutnya miskin dan ditemukan di tempat sampah.

(7) Kaya banci muka lu

\section{Kategori: Name-calling and Insult}

Data (7) memuat bentuk hinaan dengan menyebut orang lain banci. Tujuan dari penutur adalah seorang wanita juga yang dia anggap buruk/jelek. Komentar ini ditulis untuk merendahkan dan menyakiti hati.

(8) Ih upilnya uler ga tau maluu

\section{Kategori: Name-calling and Insult}

Data (8) memuat bentuk hinaan dengan menyamakan orang lain (yang juga wanita) dengan upil ular. Upil sediri berarti kotoran hidung. Tujuan penulis status adalah merendahkan dan menyakiti orang yang dia komentari.

\section{(9) Ini buritnya pasti hitam dakian lehernya aja dakian hii geli}

\section{Kategori: Sexual Harassmen, Insult}

Data (9) memuat bentuk hinaan dengan mengomentari fisik orang lain (yang juga wanita) dengan kata-kata kasar dan menyakitkan. Kata yang menunjukkan hinaan fisik adalah /buritnya pasti hitam dakian lehernya aja dakian/. Tujuan penulis status adalah merendahkan dan menyakiti orang yang dia komentari.

(10) Kayak mau ngentot

\section{Kategori: Vulgar language}

Data (10) memuat bentuk hinaan dengan menggunakan istilah vulgar. Kata ngentot sendiri berarti hubungan intim (seks). Pilihan kata yang digunakan adalah 
istilah intim yang paling kasar di masyarakat. Kata tersebut tidak layak diucapkan, apalagi di media publik.

\section{(11) Kek lonte}

\section{Kategori: Vulgar language}

Data (11) memuat bentuk hinaan dengan menggunakan istilah vulgar yang ditujukan kepada sesama wanita. Kata lonte sendiri berarti PSK (pekerja seks komersial) atau WTS (Wanita Tuna Susila) Pilihan kata yang digunakan adalah istilah yang paling kasar dan rendah di masyarakat. Kata tersebut tidak layak diucapkan, apalagi di media publik.

(12) Mel elu klo berak sambil geol2 gitu apa gak berserak taik lu Mel

\section{Kategori: Insult}

Data (12) memuat bentuk hinaan dengan menggunakan kata-kata kotor. Kata berak bermakna buang air besar, namun pilihan kata yang dituliskan itu tidak lazim dan etis untuk digunakan di ruang publik. Sama halnya dengan penggunakan kata taik yang berarti kotoran. Pilihan kata ini juga dirasa tidak sopan untuk diucapkan di media sosial. Jika dimaknai secara keselurahan, data (12) bermaksud menghina orang lain (yang juga perempuan) dengan mengucapkan kata-kata kasar dan tidak sopan.

(13) Udah kayak pelacur gretong lagi ditonton HAHA

\section{Kategori: Vulgar language, Sexual Harassment}

Data (13) memuat bentuk hinaan dengan mengumpamakan orang lain (yang juga wanita) sebagai pelacur. Selain itu, penulis komentar juga mengatakan gretongan. Gretongan merupakan bentuk slang dari kata gratisan atau cuma-cuma. Tujuan penulis status adalah merendahkan dan menghina dengan menyebut pelacur yang tidak dibayar atau diperoleh secara gratis.

(14) Dulu buto ijo skrng udah naik level jd gunderuwo

\section{Kategori: Name-calling and Insult}

Data (14) memuat bentuk hinaan dengan mengumpamakan orang lain (yang juga wanita) mirip dengan buto ijo dan gunderuwo. Buto ijo dan gunderuwo adalah makhluk gaib yang dipercayai masyarakat Indonesia sebagai sosok yang buruk dan menyeramkan. Tujuan penulis komentar adan merendahkan dan menyebut target buruk rupa. Tindakan menghina di ruang publik (media sosial) merupakan tindakan yang tidak pantas dan tidak diterima masyarakat pada masa sebelumnya.

(15) Kak saran aja, jangan jadi artis ga cocok! Cocoknya jadi pemain bokep Kak! 
LINGUA, Vol. 16, No. 2, September 2019

p ISSN: 1979 9411; e ISSN: 2442 238X

Http://lingua.soloclcs.org; Email: presslingua@gmail.com

Center of Language and Cultural Studies, Surakarta, Indonesia

Wahyuni, Wika; Mahyuni \& Mahyudi, Johan. 2019. Ekspresi Tabu Bahasa Wanita pada Status dan Komentar di Jejaring Sosial Istragram.

Lingua (2019), 16(2): 285-296. Http://doi.org/10.30957/lingua.v16i2.270.

\section{Kategori: Vulgar language, Sexual Harassment}

Data (15) memuat bentuk hinaan menyuruh orang lain (yang juga wanita) untuk melakukan hal negatif. Penulis komentar menyuruh target/sasaran untuk berperan di film bokep. Film bokep adalah film porno atau film yang memuat adegan-adegan tidak senonoh. Istilah bokep merupakan bahasa gaul yang dilabeli negatif di masyarakat. Dengan demikian, penggunaan kata tersebut dianggap tabu sehingga tidak layak diucapkan di ruang publik salah satunya media sosial instagram.

(16) Coba di cek ada ga video yang katanya sih lawyer 4 biji yang doyan maain sama perek di kota.

\section{Kategori: Vulgar language}

Data (16) memuat bentuk hinaan dengan menggunakan istilah vulgar. Kata pereksendiri berarti PSK atau WTS. Pilihan kata yang digunakan adalah istilah yang paling kasar dan rendah di masyarakat. Kata tersebut tidak layak diucapkan, apalagi di media publik.

\section{SIMPULAN}

Berdasarkan analisis pada bagian sebelumnya, dapat diperoleh beberapa simpulan sebagai berikut. Secara umum, bahasa tabu atau ekspresi tabu yang sebelumnya hanya digunakan oleh pria (dianggap wajar dan berterima), kini sudah mulai digunakan pula oleh wanita, khususnya pada media sosial instagram. Secara khusus, karakter bahasa wanita yang sebelumnya dianggap halus, santun, dan berhatihati kini mengalami pergeseran nilai sebagai akibat dari perkembangan zaman dan teknologi. Tuntutan modernitas yang menginginkan kesetaraan wanita dan pria juga berimbas pada penggunaan bahasa. Bentuk tabu berdasarkan teori ada 3, yaitu tabu yang menakutkan (taboo of fear), tabu yang menyebabkan perasaan tidak nyaman (taboo of delicacy), dan tabu yang berkaitan dengan hal-hal tidak santun dan tidak pantas (taboo of propriety).Pada penelitian ini, bentuk tabu yang ditemukan adalah jenis ketiga yaitu tabu yang berkaitan dengan hal-hal yang dianggap tidak santun dan tidak pantas (taboo of propriety). Dari 16 data yang telah diperoleh dan dianalisis, hal-hal yang dianggap tidak pantas dan tidak santun tersebut antara lain seperti penyebutan alat kelamin atau istilah yang tidak senonoh (vulgar languge, sesual harassment), makian yang merendahkan dengan kata-kata kasar, dan hinaan dengan mengumpamakan/menyamakan orang dengan hewan atau sesuatu yang dianggap buruk (name-calling and insult).

\section{DAFTAR PUSTAKA}

Chaer, Abdul dan Leonie Agustina. 2010. Sosiolinguistik Perkenalan Awal. Jakarta; Rineka Cipta

Coates, Jennifer. 1986. Women, Men and Language. London: Longman

Herdiana, Ike. 2012.Konsep Gender dan Jenis Kelamin. (Diakses pada 3 Mei 2019) 
LINGUA, Vol. 16, No. 2, September 2019

p ISSN: 1979 9411; e ISSN: 2442 238X

Http://lingua.soloclcs.org; Email: presslingua@gmail.com

Center of Language and Cultural Studies, Surakarta, Indonesia

Wahyuni, Wika; Mahyuni \& Mahyudi, Johan. 2019. Ekspresi Tabu Bahasa Wanita

pada Status dan Komentar di Jejaring Sosial Istragram.

Lingua (2019), 16(2): 285-296. Http://doi.org/10.30957/lingua.v16i2.270.

Khrisnantara, Argangga dkk. 2019. Analisis Fitur Bahasa Inggris Pada Laki-Laki Dan

Perempuan Dalam Status Instagram. (Diakses pada 20 Mei 2019)

Lakoff, R. 1975. "Language and Woman's Place”. New York: Cambridge

Mahsun. 2013. Metode Penelitian Bahasa. Jakarta: Rajawali Pers

Nur, Laily, Analisis Kata Tabu dan Klasifikasinya di Lirik Lagu Eminem pada Album The Marshal Mathers LP. Semarang

Lips, H.M. 1988. Sex and Gender: An Introduction. Mayfield Publish Company: California.

Oakley, Ann. 1972. Sex, Gender, and Society. New York: Yale University Press.

Sudaryanto. 1993. Metode dan Aneka Teknik Analisis Bahasa (Pengantar

PenelitianWahana Kebudayaan Secara Linguistis). Yogyakarta: Duta Wacara

UniversityPress.

Sumarsono. 2012. Sosiolinguistik. Yogyakarta: Pustaka Pelajar 